\title{
PIERRE MENARD VAI À WEB: NOTAS SOBRE A ESCRITA NÃO-CRIATIVA NA CONTEMPORANEIDADE
}

Sayonara Amaral de Oliveira*

\begin{abstract}
RESUMO: Neste artigo, discute-se as práticas literárias contemporâneas de apropriação e colagem textuais, disseminadas no espaço da internet. Compreende-se que essas práticas, ao elegerem uma escrita deliberadamente desprovida de criatividade e de originalidade, suscitam a reavaliação dos conceitos tradicionais de autoria e de criação no campo da literatura. Na reflexão desenvolvida, são abordadas as propostas estéticas veiculadas por dois sites em atividade na rede: poesia do google e MixLit - O DJ da Literatura. Considera-se que os exercícios de escrita não-criativa elaborados nessas propostas podem ser lidos como uma resposta afirmativa da literatura do século XXI às transformações estéticas e culturais experimentadas em tempos de mídias digitais.
\end{abstract}

PALAVRAS-CHAVE: Escrita Não-criativa. Apropriação Textual. Autoria. Mídia Digital.

"Não queria compor outro Quixote - o que é fácil - mas o Quixote. Inútil acrescentar que nunca enfrentou uma transcrição mecânica do original; não se propunha copiá-lo. Sua admirável ambição era produzir algumas páginas que coincidissem - palavra por palavra e linha por linha - com as de Miguel de Cervantes." (BORGES, 199, p. 52). Nesse trecho do instigante "Pierre Menard, autor do Quixote", Jorge Luis Borges resume a tarefa excepcional a que se dedicou o seu protagonista: escrever um texto literalmente idêntico ao alentado texto de Cervantes, uma espécie de palimpsesto que, produzido três séculos depois, repetisse o livro preexistente.

Entre as sugestivas interpretações que a ficção teórica montada por Borges lança aos estudiosos de literatura, destaca-se o extravio dos critérios de originalidade e autenticidade, tal como estes foram sedimentados pela cultura artística da modernidade, desde que se institui o privilégio da expressão estética individual ou

\footnotetext{
* Universidade do Estado da Bahia, Brasil. E-mail: sayo22@terra.com.br 
autoral. Ao tomar posse da escrita alheia, Menard opta por repetir em vez de criar, negando também, por extensão, o atributo romântico da livre imaginação, princípio caro no campo literário moderno, o qual é transmitido e validado, com maior ou menor intensidade, até os dias de hoje. Como observa Silviano Santiago (2000), a singularidade do projeto absurdo de Pierre Menard reside na sua recusa à liberdade de criação, com vistas a instaurar a prisão ao modelo como forma de conduta, indo na contramão da postura que tradicionalmente regula o pensar a arte como produto de uma espontaneidade criadora ou fruto do acaso.

Ao assumir um procedimento estético que implica em voluntariamente suprimir sua voz pessoal, o gesto empreendido por Pierre Menard traduz ainda, de forma paradoxal, uma inusitada autonomia, por conferir à experiência da leitura uma concepção singular. Considerando que Menard se faz leitor de Cervantes, o ato de ler, longe de configurar uma prática passiva, subserviente, emerge aqui em seu caráter produtivo e, por certo, irreverente: ler é desafixar a identidade de um texto e proceder por deslocamentos, anacronismos, pelo jogo das "atribuições errôneas" (BORGES, 1999, p. 57). Com a decisão de reescrever o que foi escrito e assinado por outrem, o método de leitura aí instaurado deflagra que no território híbrido e difuso da linguagem não existe lugar para um dizer próprio, primeiro e original, havendo tão somente sucessões de leituras e apropriações. "O paradoxo cômico de Menard mostra, por meio de seu escândalo lógico, que todos os textos são reescrita de outros textos (num desdobramento especular, oblíquo e infinito de sentidos)", conforme ressalta Beatriz Sarlo (2008, p. 66-67).

\section{Originalidades em baixa}

Produzido no final dos anos 1930, o texto de Borges ilustra, em caráter precursor, uma orientação estética muito próxima do que vem se chamar de escrita nãocriativa (uncreative writing) na cultura contemporânea. A expressão, difundida pelo escritor e artista plástico nova-iorquino Kenneth Goldsmith, designa um conjunto de técnicas de escrita que empregam, entre outros registros, estratégias de replicação e pirataria de textos (considerados literários ou não) como métodos 
de composição literária. Para Goldsmith, no contexto das mídias digitais, quando o compartilhamento de arquivos e a mixagem generalizada põem em relevo o desgaste das noções convencionais de criatividade e originalidade, cabe ao escritor procurar "novos modos de escrita, que usam textos já existentes, que decidem usar as vozes de outros e tomar como próprias, repetindo o processo 'ad infinitum' e refletindo a sala de espelhos digital que é a internet" (GOLDSMITH, 2013). ${ }^{1}$

A prática da apropriação textual, que não constitui novidade como manifestação da cultura, incide numa questão delicada para o campo literário, desde que a função autor (Foucault, 2002) regula o regime de propriedade das obras nas sociedades modernas: o plágio. Ao contrário do que ocorria em tempos antigos, quando $o$ ato de plagiar (tal como hoje se nomeia) não era sequer cogitado a título de problema - e a qualidade de um texto se media pela habilidade do seu criador em citar os textos pertencentes à tradição na qual ele procurava se inserir -, ser identificado como um plagiador, a partir da modernidade, significa arrastar consigo o estigma da desonestidade, bem como a desconfiança sobre a sua capacidade intelectual para criar obras singulares e autênticas.

Mesmo agora, numa época de cultura digital expandida, de softwares livres, creatives commons e autorias interativas em rede (MARTINS, 2014), levando a repensar as antigas fronteiras da propriedade autoral, ainda parece válida a observação de Michel Schneider (1990, p. 59), quando diz: "Não há pior atributo associado ao nome de um escritor que o de plagiário. [...] Confessar-se um plagiário seria reconhecer uma insuficiência de imaginação, um defeito do próprio pensamento, uma lacuna em sua criatividade." Além das complicações jurídicas

\footnotetext{
${ }^{1}$ Kenneth Goldsmith é criador e curador do site Ubuweb, que abriga um imenso acervo virtual de arte experimental. Entre os seus projetos literários, destacam-se, entre outros, os volumes de sua "Trilogia de Nova York". O primeiro deles, The Weather (2005), é composto pela transcrição de previsões do tempo fornecidas por uma estação de rádio. No segundo, Tráffic (2007), encontra-se o registro de um período de 24 horas de relatórios do trânsito. E por último, Sports (2008), que apresenta a transcrição na íntegra de cinco horas de um jogo de beisebol, conforme narrado pelos seus comentaristas esportivos. Até o momento, apenas o seu livro Tráffic foi traduzido e publicado no Brasil, numa versão modificada e mais compacta do que a edição norte-americana. Com o título Trânsito, o livro, assinado por Marília Garcia e Leonardo Gandolfi, foi lançado pela Luna Parque Edições em 2016.
} 
em torno dos copyrights, o plágio inscreve uma marca de rasura sobre o capital simbólico do produtor literário, colocando sob suspeita o seu valor profissional no espaço em que se legitima. Daí que episódios de "pirataria literária", identificados com frequência em publicações do século XXI, continuem a provocar desconforto junto a escritores, críticos, professores e demais agentes do campo, muitos dos quais resistem à iniciativa de redimensionar o seu entendimento dos conceitos de autoria e de literatura - atitude que se faria fundamental para lidar com as práticas literárias do presente, como observa Luciene Azevedo (2011).

Mas a escrita não-criativa não se deixa abater pela carga cultural negativa que pesa sobre a categoria do plágio. A ausência de originalidade, que no caso do plágio pode se configurar em delito passível de punição e, por vezes, motivo de constrangimento, está aqui exaltada como o protocolo chave da composição artística, como o seu leitmotiv. O produtor não-criativo se autodeclara um hacker ou saqueador de palavras e extrai destes atributos a sua legitimidade, forçando os limites das noções de autoria e de criação, com as quais o campo artístico e literário se habituou a lidar ao longo da modernidade. Tal produtor estaria agindo de forma semelhante a outra das personagens plagiárias de Borges (em parceria com Adolfo Bioy Casares) - César Paladion -, cuja decisão de publicar obras alheias na integra, substituindo o nome dos autores pelo seu próprio nome, justificava-se pelo seguinte princípio: "publicar livros que o exprimissem, sem sobrecarregar o impressionante corpus bibliográfico já existente, nem cair na vaidade de escrever uma única linha por si mesmo" (Apud COMPAGNON, 2007, p. 154).

Na escrita não-criativa, é fundamental realçar o processo de apropriação e pilhagem dos textos alheios, importando mostrar o que se pode fazer com esses discursos, em vez de apostar naquilo que se acreditaria (ou pareceria) ser a expressão de uma fala autêntica. Diante dessa proposta, longe de se buscar identificar o que seja próprio e alheio nos textos postos em jogo na apropriação, com o intuito de promover uma espécie de acareação entre a obra-fonte e suas reprises, todas as atenções devem se voltar para o potencial da ideia e do método 
de composição aí agenciado, razão pela qual essa produção se inscreve no registro de uma arte conceitual, como explica o próprio Goldsmith:

\begin{abstract}
A escrita conceitual ou não criativa é uma poética do momento, que funde os impulsos de vanguarda do último século com as tecnologias do presente, uma [poética] que propõe um campo expandido para a poesia do século XXI [...] a escrita conceitual, obstinada, não faz qualquer alegação de ser original. Pelo contrário, ela emprega intencionalmente táticas de apagamento do ego através da falta de criatividade, de originalidade, de legibilidade, da apropriação, do plágio, da fraude, do roubo e falsificação de seus preceitos; gerenciamento de informação, processamento de texto, bancos de dados e o processamento extremo como metodologias (GOLDSMITH Apud PERLOFF, 2013, p. 244).
\end{abstract}

As táticas de apagamento do ego e o elogio da falta de criatividade exigem que se revise a noção de genialidade, separando-a do seu correlato mais comum - a originalidade. Tal correlação, cumpre lembrar, encontra a sua fórmula acabada na estética de Kant (2005, p. 153), que, ao tratar do gênio na arte, pronuncia-se do seguinte modo: "seus produtos têm que ser ao mesmo tempo modelos, isto é, exemplares, por conseguinte eles próprios não surgiram por imitação." Assim, define-se o original como não derivado ou não dependente de qualquer outra coisa, como nunca imitado de outrem. E essa definição se modula à concepção clássica, aurática, de gênio e seus desdobramentos nas noções de genuíno, autêntico, único - critérios de alta cotação no mundo da arte, desde pelo menos fins do século XVIII.

Ora, com a escrita não-criativa do século XXI, é possível produzir textos instigantes, fascinantes, sem ser necessariamente original, ou melhor: justamente por renunciar ao que seja "original", adotando tal renúncia como projeto literário. Essa é a reflexão desenvolvida pela crítica norte-americana Marjorie Perloff (2013, p. 54), quando afirma: "se a nova poesia 'conceitual' não alega possuir qualquer originalidade - ou pelo menos a originalidade no sentido comum - isso não quer dizer que não haja um gênio em jogo. São necessárias apenas formas distintas." O texto não-criativo, por mais que se declare inautêntico e não-original, será sempre o produto de escolhas do indivíduo, o qual pode inclusive ser reconhecido como "genial" por seus admiradores, sendo que os motivos para tal reconhecimento não continuam os mesmos que foram instituídos na estética 
kantiana. Posto sob rasura, o conceito de gênio vem agora designar as habilidades para a apropriação, a reprodução e a colagem, assumindo-se a imitação calculada como um valor positivo.

É nítido o diálogo com projetos estéticos como o de Marcel Duchamp, cuja obra se constrói de cópias e materiais "achados", além da influência de outros movimentos artísticos do século $X X$, os quais também fizeram do conceito o objeto da arte ou questionaram noções ortodoxas de criação e de autoria, a exemplo dos situacionistas, dos concretistas, da Oulipo (Oficina de Literatura em Potencial), para falar aqui de apenas algumas vertentes. Como observa Marjorie Perloff (2013), ao discutir o que entende ser essa literatura praticada por intermédio de outros métodos na contemporaneidade, trata-se de uma poética que remonta a uma série de movimentos e paradigmas que a antecederam em décadas. Negar-se ao original não é, portanto, um gesto inédito no mundo da arte. Porém, agora, o mais significativo reside na adequação da proposta ao meio de que esta se serve - a internet:

\begin{abstract}
A citacionalidade - com sua dialética de remoção e enxerto, disjunção e conjunção, sua interpenetração de origem e destruição - é central para a poética do século 21. De fato, a récriture, como chama Antoine Compagnon, é a forma lógica da "escrita" numa era em que o texto é literalmente móvel ou transferível - texto que pode ser prontamente deslocado de um local digital para outro ou impresso a partir do monitor, que pode ser apropriado, transformado ou ocultado por todos os tipos de métodos e para todos os tipos de propósitos (PERLOFF, 2013, p.48, grifo da autora).
\end{abstract}

Levando-se em conta a relevância que as chamadas novas tecnologias têm hoje na vida das pessoas, resta indagar: como a literatura vai reagir diante desse ambiente movediço de fluxos e conexões em rede? É a partir de perguntas como esta que Goldsmith formula o seu projeto de uma arte sem criatividade, estando ciente de que os procedimentos de apropriação e reciclagem, muito bem recebidos no universo das artes visuais e também da atual cultura eletrônica, não têm a mesma força no campo da escrita literária. Nos seus termos, "do Napster aos games, do karaokê aos arquivos torrent, a cultura parece estar aderindo ao digital e a toda a complexidade que ele traz - com exceção da escrita, a qual 
ainda está ligada principalmente à promoção de uma identidade autêntica e estável a qualquer preço" (GOLDSMITH, 2011a, p. 7). Há quem ainda espere do escritor a palavra primária, espontânea e inaugural, que faça jus a um suposto ato de criação ex nihilo. Mas é evidente que tal expectativa sobre o processo criativo entra em descompasso com as transformações estéticas e culturais que se avolumam na paisagem digital, território ímpar do processamento de textos, da programação de dados e de incontáveis possibilidades de trocas e pilhagens.

\section{Texturas replicadas, mixagens literárias}

Experiências poéticas realizadas com sites de busca na internet têm se revelado um terreno profícuo para o exercício de uma escrita desprovida de aspirações criadoras, considerando os questionamentos que hoje se impõem ao sentido ortodoxo do termo criação. Caso exemplar é o da "poesia do google", que pode ser encontrada no site com o mesmo nome e cujo projeto original (google poetics) surgiu em inglês e finlandês, em 2012, sendo rapidamente difundido e traduzido em diversos países. ${ }^{2}$

A proposta consiste em compor poemas a partir do sistema automático de buscas do google. Digita-se alguma palavra, expressão ou mesmo uma letra na caixa de pesquisa e o algoritmo do buscador "prevê" e apresenta consultas de pesquisa baseadas em um histórico de atividades de outros usuários. Os resultados vão variar conforme a versão do buscador utilizada: google.com ou google.com.br, entre outras. As frases surgidas de maneira aleatória irão compor o poema, cabendo ao poeta usurário da tecnologia congelar e registrar a composição através do recurso de print screen (captura da imagem na tela), enviando-a posteriormente para a postagem no site. Nesse jogo com a indeterminação e o acaso na linguagem, lembrando o non sense da estética dadaísta, que propunha compor poemas a partir do sorteio de palavras recortadas de artigos de jornal, flagra-se o efeito e/ou conceito poético a partir das combinações geradas por

\footnotetext{
2 A "poesia do google" se apresenta como um tumblr (microblog) coletivo de poesias, que não possui filiação com a empresa Google Inc, segundo informação postada na homepage do site. O endereço do tumblr em português é: <http://poesiadogoogle.com>.
}

Texto Digital, Florianópolis, Santa Catarina, Brasil, v. 12, n. 2, p. 124-144, jul./dez. 2016. ISSNe: 1807-9288. 
intermédio da máquina. Abaixo segue um exemplo, apresentado tal como foi extraído da página eletrônica:

Fig. 01 - Não é porque: sugestão de \#PoesiadoGoogle enviada pelo Pedro Cassel

New Tab

C Q não é porque

não é porque - Google Search

Q não é porque o céu está nublado que as estrelas morreram

Q não é porque eu sujei a roupa bem agora que eu já estava saindo

Q não é porque tá muito frio não é porque tá muito calor

Q não é porque ele é meu pai

$Q$ não é porque um espinho te feriu

Fonte: CASSEL, poesiadogoogle.com

Como um banco de dados continuamente acessado, o google está sempre se atualizando, o que torna imprescindível capturar de imediato na tela a composição de frases surgida, para não se correr o risco de perdê-la em outras tentativas de busca. Essa é a orientação dada pelo curador do site no Brasil, o escritor e jornalista Davi Carneiro, no texto de apresentação da proposta. Em seus termos, "a intenção é compartilhar resultados criativos. Que fujam do comum. Que acrescentem um pouco de poesia ao nosso cotidiano, muitas vezes, tão mecânico e sem inspiração" (CARNEIRO, poesiadogoogle.com). Legado das estéticas formalistas e de vanguarda do século $X X$, esse objetivo de desautomatizar a linguagem, de subtraí-la do fluxo contínuo de informações que abarrotam o cotidiano, realiza-se através do recurso de automatização que os códigos de programação do google têm a oferecer e dos quais o poeta, usuário da tecnologia, deve tirar proveito.

Potencializa-se a compreensão do ambiente digital como território do hipertexto, configuração que "traduz de modo radical a materialidade da noção de obra aberta que funda a possibilidade de experimentação ilimitada", como observa Heidrun Krieger Olinto (2002, p. 70). O hipertexto digital, grosso modo, define-se 
por uma estrutura discursiva em rede, isto é, por uma teia cujos fios partem de um ponto a outro do espaço virtual, sem origem certa ou sequência definida. $O$ arranjo errático de frases que se conectam para dar forma à poesia do google constitui uma espécie de ponto de chegada desses fios difusos, colhidos da massa caótica de conteúdos depositados pelos usuários na internet a cada segundo. Como lugar de encontro de ramificações múltiplas, o poema de buscadores não pode, portanto, ser tomado como exemplo de unidade ou uniformidade textual, sendo também inviável atribuir-lhe uma essência fundante ou marcas de procedência.

Nas páginas do sítio coletivo poesiadogoogle.com, em meio ao mosaico de produções majoritariamente anônimas, alguns dos poemas "printados" trazem assinaturas individuais de seus autores. Contudo, é evidente que a noção de autoria não pode ser aqui tomada em seu valor pleno, o qual, conforme Michel Foucault (2002), consistiria em situar no indivíduo particular o lugar originário de sua escrita. Nos poemas em questão, a ausência de origem/originalidade se traduz pelo efeito da despersonalização, da destituição da personalidade criadora, por assim dizer. O poeta do google acessa e recolhe os dados que compõem os denominadores comuns da maioria de buscas textuais realizadas na rede, fornecendo uma amostra do "senso comum social", como observou o poeta e ensaísta Danilo Augusto (2014). Ainda que haja um indivíduo mediando a compilação de frases capturadas e replicadas maquinalmente pelo gigantesco navegador do google, não resta lugar para se pensar numa emissão própria - a matriz ou fonte de onde jorram, definitivamente, as palavras.

"Não sabe o autor que o nome é a única coisa do livro que ele poderia dizer sua, que nunca assina senão por procuração [...]? - indaga Michel Schneider (1990, p. 135), ao expor o raciocínio segundo o qual os escritores ocupam apenas o lugar de tutores dos textos que publicam, concebendo-se a escritura como sendo sempre a utilização desviada das palavras do(s) outro(s). O gesto signatário dos poetas do google se realiza mediante esse princípio de enfraquecimento da voz e da instituição autoral, vindo a representar menos a demarcação do selo de 
propriedade do que um registro acessório, conferido ao texto a título de empréstimo. Emblematicamente, nos créditos do poema, quando estes são registrados no site, a expressão "criação", acompanhando a assinatura do poeta, dá lugar ao termo "sugestão", de modo a relativizar o status do poder demiúrgico e o sentido de autoridade que uma rubrica de artista tradicionalmente veicula.

Como mostra de uma tendência que se inscreve no ambiente digital através de experiências de colagens e apropriações textuais, as quais dão corpo a produções de uma já nomeada literatura cut-up ${ }^{3}$ e copy \& paste, outra iniciativa instigante pode ser encontrada no site brasileiro MixLit: O DJ da Literatura ${ }^{4}$, com a diferença de se tratar agora de um projeto individual, portanto, autoral - o que não significa dizer que a noção de autoria permaneça aqui intacta. Nesse projeto, o escritor Leonardo Villa-Forte, proprietário do site, assume a empreitada de redigir, publicar e assinar textos compostos integralmente a partir de trechos extraídos de obras de escritores diversos, os quais ele recorta e "cola", operando ao modo dos recursos fornecidos pelos programas editores de textos. Ao atar fios entre a experiência da escrita literária e outras práticas e manifestações artísticas da cultura pop contemporânea, a técnica de composição aí empregada remete às remixagens e sampleamentos operados no campo da atual música eletrônica, razão pela qual Villa-Forte se autointitula "o $D J$ da literatura."

É possível inserir o procedimento estético adotado pelo MixLit no ramo das artes de pós-produção - termo técnico empregado nas áreas do cinema, da televisão e do vídeo, mas praticamente desconhecido no campo da literatura, dada a prominência que este último conferiu à criação, tida como um produto final, acabado, impermeável a intervenções ulteriores. De acordo com o crítico de arte

\footnotetext{
${ }^{3}$ A expressão cut-up, que em tradução livre significa "corte", "recorte", foi difundida nos anos 1960 pelo escritor norte-americano William Burroughs para dar conta se seus experimentos estéticos com colagens textuais, abarcando tanto materiais impressos quanto de áudio e de vídeo (DIÓGENES, 2012).

${ }^{4}$ Disponível em: <https://mixlit.wordpress.com>.

${ }^{5}$ Além de projeto Mix Lit, Leonardo Villa-Forte é criador da Intervenção Urbana Paginário, tendo também publicado trabalhos em livros coletivos e individuais. Estes últimos compreendem o livro de contos O explicador (2014), o romance O princípio de ver histórias em todo lugar (2015), ambos publicados pela editora Oito e Meio, e também o conto Agenda (2015), em edição artesanal, publicada pelo selo Megamíni.
} 
Nicolas Bourriad (2009, p. 7-8), a pós-produção - que de início "designa o conjunto de tratamentos dados a um material registrado: a montagem, o acréscimo de outras fontes visuais ou sonoras, as legendas, as vozes off, os efeitos especiais" - serve agora para definir uma multiplicidade de formas por meio das quais artistas contemporâneos vêm "interpretando, reproduzindo, reexpondo ou utilizando produtos culturais disponíveis ou obras realizadas por terceiros".

As atividades acima mencionadas têm nas figuras do $D J$, do programador e do internauta a sua representação mais contundente. Estes não se ocupam de criar formas novas ou originais, antes, eles atuam sobre aquilo que já foi executado por alguém. Os artistas da pós-produção, abolindo a aura romântica cultivada em torno da figura do autor inspirado e gênio, inventam itinerários por entre a cultura e constroem protocolos de uso para signos e estruturas aí existentes. E nesse processo de intervenção sobre um produto artístico dado, altera-se o próprio estatuto da obra de arte, a qual, uma vez reinvestida, retrabalhada, passa a ser interpretada como uma forma provisória, inacabada, considerando as operações potenciais que esta obra ainda pode suscitar.

"Inventariar e selecionar, utilizar e recarregar" (BOURRIAUD, 2009, p.109). Estes são os termos-chave das artes de pós-produção, que se aproximam dos princípios norteadores da escrita não-criativa, defendida por Keneth Goldsmith, e encontram solo fértil no projeto de mixagem literária articulado no site MixLit. Em suas incursões nos trechos que recolhe de variadas produções literárias, a fim de posteriormente reuni-los em nova composição, Leonardo Villa-Forte ocupa o lugar do programador de textos ou do "autor montador", como ele próprio afirma no site, o que se pode constatar no exemplo transcrito a seguir:

MixLit 55: Uma visita à sra. Mercado

Sentada no parapeito, cabisbaixa, imersa em pensamentos 1 , embriaguez $\underline{2}$, juntamente alegre e triste $\underline{3}$, a sra. Mercado só percebeu a nossa aproximação quando Poirot estacou diante dela e a saudou4 4 - Q-q-quanto é? $\underline{5}$ 
Ela ficou curiosa pela figura: terno, gravata, o cabelo penteado com capricho, mudando do cinza pro grisalho. Um coroa, mais um. Estava se especializando no antendimento à terceira idade $\underline{\text {. }}$.

- Quanto você tem aí?

Viuva, baixinha, feia, gordinha ${ }^{8}$, um hálito de mamute 9 . Só não tenho medo dela quando estamos na cama ${ }^{10}$, eu disse 11 , De bom não tem nada, nem o exotismo $\frac{12}{2}$.

— Que importa? $\underline{13}$, me disse $\underline{14}$ Poirot $\underline{15}$ — Xá comigo! 16

— Faça bom proveito!17

Acendi um cigarro, ele trouxe uma garrafa de cerveja, dois copos, não podia ver ninguém bebendo sozinho, "Me dá aflição!", brindamos, sumiu atrás da mulher 18 .

Meu respeito por ele aumentou 19 .

1 Agatha CHRISTIE Morte na Mesopotâmia. Tradução de Henrique Guerra. Rio Grande do Sul: L\&PM, p.168.

2 Marçal AQUINO. Eu receberia as piores noticias dos seus lindos lábios. Sã o Paulo: Companhia das Letras, 2009, p. 85.

3 Machado DE ASSIS O alienista. Rio Grande do Sul: L\&PM, 1998, p.87.

4 Agatha CHRISTIE. Idem.

5 Atiq RAHIMI. Syngué sabour - Pedra-de-paciência. Estação Liberdade.

P.110.

6 Marçal AQUINO. Idem.

7 Atiq RAHIMI. Idem, p.111.

8 Muriel BARBERY. A elegância do ouriço. Tradução de Rosa Freire

D`Aguiar. São Paulo: Companhia das Letras, 2008, p.115.

9 Muriel BARBERY. Idem.

10 Péter ESTERHÁZY. Uma mulher. Tradução de Paulo Schiller. São

Paulo: Cosac Naify, 2011, p.96.

11 Marçal AQUINO. Idem, p.217.

12 Péter ESTERHÁZY. Idem, p.83.

13 Machado DE ASSIS. Idem, p.25.

14 Luiz RUFFATO. Estive em Lisboa e lembrei de você. São Paulo: Companhia das Letras, 2009, p.19.

15 Agatha CHRISTIE. Idem.

16 Luiz RUFFATO. Idem.

17 Muriel BARBERY. Idem, p.34.

18 Luiz RUFFATO. Idem.

19 Agatha CHRISTIE. Idem, p.171.

(VILLA-FORTE, MixLit: o DJ da Literatura)

Deslocar e realocar trechos de diferentes obras, de modo a compor uma narrativa coerente a partir dos retalhos justapostos. Combinar fragmentos de produções pertencentes a gêneros textuais diversos, com direito a mesclar inscrições de vocabulário que vão do registro popular ao erudito e vice-versa. Acionar diálogos entre personagens, cenas ou situações criadas por autores de estilos, épocas e nacionalidades distintas. Cuidar para que todo o texto seja confeccionado estritamente com transcrições de discursos já publicados, mesmo quando se trata de unidades mínimas da frase ou de expressões facilmente encontradas no linguajar do senso comum. Referenciar, minuciosamente e com rigor técnico, 
todas as citações utilizadas para compor o remix literário, expondo, assim, um repertório seletivo de leituras. Eis uma lista de tarefas assumidas pelo escritor $D J$.

Nas notas de "pé de página", o registro das referências aos escritores citados, permite que o orquestrador de discursos se resguarde perante as leis de propriedade autoral. Essa precaução pode ser constada em postagem afixada na homepage do site: "se você é ou representa algum dos autores remixados aqui e se incomodou com a utilização de trechos de seus textos, entre em contato conosco e logo retiraremos a passagem em questão" (VILLA-FORTE, MixLit: O DJ da Literatura). Contudo, para além da justificada cautela com questões legais, o gesto de fornecer devidamente os endereços dos trechos transcritos vai revelar o próprio motivo estético do MixLit, razão de ser da escrita não-criativa em sua dimensão de arte-conceito.

A iniciativa de tomar diferentes autores para lhes atribuir até as expressões mais corriqueiras ("que importa?", "eu disse", "me disse"), não funciona apenas para sugerir, de maneira quase anedótica, que qualquer discurso pode estar em todo lugar, à revelia de quem o assine ou o autorize - ao fim e ao cabo, a rubrica autoral não passa de uma operação arbitrária. Em acréscimo a este importante entendimento, a manutenção das assinaturas como selos de propriedade também permite deixar à mostra a imposição de um método, de uma restrição formal, levando ao limite a compreensão de que a técnica da colagem é aqui um desafio estético e, como tal, trabalho de oficina. O desafio consiste em obrigar-se a não emitir nenhum discurso que não seja assinado por outro(s). Como afirma o próprio Villa-Forte, ao discorrer sobre o esforço empenhado no processo de suas mixagens:

Parto da regra de que não posso escrever nada com minha própria mão. [...] Na criação de mão própria posso guiar a frase como bem entender, desde suas mínimas até as máximas unidades, estabelecer um ritmo e levar a narrativa para onde eu quiser. No MixLit, apesar da ideia de que posso levar para onde eu quiser, na verdade não posso, pois estou restrito àquilo que oferecem os livros que tenho (VILLA-FORTE, baixacultura.org). 
A obediência ao esquema de colagem e a recusa à liberdade para criar um discurso próprio são, portanto, a condição imprescindível para o exercício literário que o remix exige. E nessa operação de "escrita-através" (PERLOFF, 2013) dos outros, em que pesa mais a edição que a "criação", a assinatura que o escritor DJ imprime às suas produções remete menos ao indivíduo-autor do que a um invasor de mãos e falas alheias. Ao mesmo tempo, pode-se divisar aqui um modo particular de composição, decorrente das escolhas feitas e do tratamento meticuloso conferido a essas escolhas, o que leva a constatar que a restrição autoimposta pelo $D J$ de palavras não descarta a existência de sua intervenção individual, apenas a situa sob outra perspectiva, distante do antigo binômio originalidade-genialidade.

Ainda que não recorra à internet como ferramenta para a confecção dos remixes - diferentemente do projeto poesia do google, que faz da tecnologia da rede a base indispensável da composição poética -, o MixLit também explora, em sua configuração, o potencial de abertura característico do hipertexto. Porém, agora, o esfacelamento da ideia de unidade não prescinde da remissão aos nomes de autores dos trechos apropriados. As rubricas autorais são lançadas em notas no rodapé do texto, as quais funcionam como links para o texto mixado e projetam, em relação a este, uma leitura fraturada, em forma de zigue-zague. Extensivamente, as rubricas também se agrupam em um menu de tags (etiquetas digitais que servem para relacionar informações) na homepage do site. Quando seleciona ("clica") uma dessas tags, o usuário/leitor tem acesso "instantâneo" a um arquivo de todos as colagens nas quais o nome do autor relacionado aparece, o que the permite navegar por uma constelação de assinaturas e fragmentos difusos mas conectáveis, os quais dão forma à ideia de um "livro infinito", como pretende o próprio Villa-Forte:

\footnotetext{
Sinto como se colocasse os livros para conversar e fosse, aos poucos, construindo um livro infinito, um livro que transborda suas páginas, como se certa linha de uma livro escapasse do limite do seu papel e fosse se esticando e esticando até repousar em outra linha, de uma outra página, de um outro livro. Uma linha infinita que poderia nunca acabar, e pela qual todos os livros pudessem dar as mãos (VILLA-FORTE, baixacultura.org).
} 
Conceber as produções literárias como conjuntos de dados móveis, disponíveis à manipulação e ao intercâmbio, é uma maneira de dessacralizar o status da obra artística em seu caráter de produto definitivo e, portanto, inviolável. A esse propósito, é emblemático que na feitura dos remixes pareça haver uma predileção por trechos extraídos de livros. O livro impresso, com sua capa e miolo tradicionais, com seu volume e forma delimitados espacialmente, é a própria representação material de um bloco encerrado, acabado - um "pequeno paralelepípedo" que se tem na mão, como dirá Michel Foucault (2005) ao tratar da pretensa noção de unidade sobre a qual o objeto livro repousa. Diante de um tal objeto, é comum esquecer que se trata apenas de um invólucro a enfeixar um sem número de remissões a outros textos. Mas é justamente essa aparência de finitude e de unidade que cumpre agora abalar com a técnica do remix. O abalo é posto em prática na medida em que, ao entrar e sair das páginas alheias, o escritor $D J$ executa o laborioso trabalho da citação, deflagrando todo o caráter invasivo e afirmativamente predatório desta atividade, conforme descrito por Antoine Compagnon (2007, p.13): "quando cito, extraio, mutilo, desenraizo. [...] Porque minha leitura não é monótona nem unificadora; ela faz explodir o texto, desmonta-o, dispersa-o."

Citar obras representa uma maneira de homenageá-las, de (re)canonizá-las, mas não sem antes mutilá-las, fazendo com que cada trecho amputado se descole do seu contexto de enunciação original e escape dos domínios de seu criador. Considere-se a concepção de propriedade intelectual pela clássica associação estabelecida entre o autor e a figura paterna, usualmente encontrada nos dicionários: "Autor - aquele de que alguém ou alguma coisa nasce ou procede. [...] Autor de seus dias: o pai" (MICHAELIS). Não é por acaso que Leonardo VillaForte recorre à representação simbólica da "família" quando define, alegoricamente, o objetivo que traça para as suas produções: "proporcionar algo como uma vida bastarda aos trechos utilizados, jogando-os entre irmãos de diferentes pais, e de alguma forma tentando ver nisso a máxima de que a literatura nasce do mundo para o mundo" (VILLA-FORTE, MixLit: O DJ da Literatura). 
Instrumentos de desapropriação, entregues à orfandade e à clandestinidade, os trechos recortados e recombinados na forma do remix literário podem finalmente ser cogitados como um bem simbólico de todos - "do mundo para o mundo" princípio válido também para a poesia de buscadores, em sua replicação dos fragmentos anônimos que flutuam na rede. Este é possivelmente o mote a deflagrar nos exercícios de escrita lançados por alguns produtores literários, os quais, em tempos de cultura eletrônica e digital, desenvolvem suas performances como Djs, hackers, programadores. Além da evidente influência dos novos meios tecnológicos nesses atos de escrita, o mote se traduz pelo entendimento de que todo texto é construído a partir de remissões a outros textos preexistentes e disseminados na cultura, em um processo que não dá a conhecer a noção de origem e muito menos a de propriedade. "Vivo em um mundo povoado de palavras alheias. E toda a minha vida, então, não é senão a orientação no mundo das palavras alheias [...]," como disse há um bom tempo Mikhail Bakhtin (2003, p. 347).

Mediante os usos das ferramentas disponibilizadas pelas mídias digitais em rede, o pensamento veiculado na antológica sentença bakhtiniana, bastante conhecido entre estudiosos da área da linguagem, encontra espaço para ser cultivado em meio a um público amplo e não especializado. Ocorre que a compreensão da linguagem como uma malha cambiante de palavras e vozes sociais, a extrapolar os domínios de um indivíduo-autor, alcança concretude nas mais diversas operações realizadas cotidianamente por usuários da internet. Um dos exemplos pode ser identificado no gesto recorrente de compartilhar arquivos próprios e alheios, "recortando" e "colando" conteúdos os mais diversos, o que presta contas das propriedades singulares do texto eletrônico: um texto que pode ser manipulável, "procurável", transmissível instantemente (SANTAELLA, 2007). Uma segunda opção é a escrita colaborativa em rede, desde as postagens de comentários de leitores que interagem ou dialogam com o texto principal de um blog até as propostas de sites constituídos exclusivamente de autorias compartilhadas, como o conhecido Wikipédia. Outros casos atingem mais 
diretamente a questão dos direitos de propriedade autoral pelas vias do plágio e da apocrifia, na medida em que os usuários assinam textos de outros, tomandoos como seus, ou ainda quando produzem os seus próprios textos e os fazem circular com assinaturas de autores famosos, construindo assim uma rede de falsas atribuições (RÓNAI, 2006).

São essas práticas difusas de apropriação, expropriação e circulação de textos que os produtores não-criativos realimentam ou "recarregam", como diria Nicolas Bourriad (2009), e transformam em conceito e objeto estéticos. A busca de não ser original a todo custo, exaltando uma escrita de segunda mão, de modo a causar ranhuras no que Roland Barthes (1988) chamou de "império do autor", depõe sobre atividades que são rotineiras entre internautas hoje. Capturadas do emaranhado de conteúdos que abundam na rede e sendo uma vez projetadas como fruto de um trabalho refletido sobre a linguagem, aquelas atividades adquirem o status de produto artístico, com direito a site próprio e a uma rubrica (individual ou coletiva) que as enfeixa e as valida. E é na condição de produto artístico que as técnicas da cópia, do saqueamento e da colagem, após serem reelaboradas esteticamente, são de novo postadas na internet e devolvidas aos usuários da mídia para sua apreciação.

De acordo com Goldsmith (2011b), se no contexto contemporâneo "a tecnologia muda as regras do jogo em todos os aspectos de nossas vidas", é preciso apostar com urgência em métodos de escrita que levem "a reimaginar o nosso relacionamento normativo com a linguagem." $\mathrm{Na}$ internet, os produtores nãocriativos levam adiante essa aposta à medida que ressignificam os usos habituais que, no interior do ambiente da rede, são feitos da linguagem. Retira-se a cultura da colagem, da citação e do plágio eletrônicos de sua dimensão já normativa, ao se apresentar proposições inusitadas para práticas muitas vezes desgastadas. $\mathrm{E}$ nesse gesto - contrariando um certo pensamento pessimista, o qual lamenta a possível perda de espaço para o fazer literário frente à expansão das chamadas novas tecnologias - enxerga-se a resposta afirmativa que a literatura oferece diante das transformações vivenciadas em tempos de mídias digitais. Mídias 
cujos usos crescentes e multifacetados podem servir também como motivo ou matéria de criação, muito longe da apatia que, segundo uma visão apocalíptica, marcaria a cultura digital como pura cultura de entretenimento.

Se as modalidades de apropriação e colagem literárias aqui abordadas, assim como outras tantas que circulam pela rede, não representam novidade em relação ao que se fez no passado, isso não quer dizer que não haja diferenças, pois é certo que, diante das tecnologias do século XXI, possíveis iniciativas estéticas que antes estariam circunscritas a pequenos grupos dos chamados artistas e intelectuais de vanguarda, encontram-se agora disponíveis e acessíveis a públicos amplos, os quais vão poder ali reconhecer as suas práticas cotidianas, bem como apreciar o potencial artístico que delas se extrai. Diante dos sítios e circuitos virtuais de escrita não-criativa, esses públicos podem inclusive aderir a tais projetos na condição de produtores também, contando com a chance de experimentar a genialidade de tarefas como aquela a que se impôs Pierre Menard, em sua aventura deliberada de não ser um escritor espontâneo e original - ciente de que ninguém jamais o foi. Que façam bom proveito.

\section{PIERRE MENARD ON THE INTERNET: NOTES ON UNCREATIVE WRITING IN CONTEMPORANEITY}

ABSTRACT: In this article, the contemporary literary practices of appropriation and textual collage are discussed as disseminated on the internet. These practices are thus understood as being practices that elect deliberately a writing style, lacking creativity and originality and raising a reevaluation of traditional concepts of authorship and creation in the literature field. In the reflections raised here, the esthetical proposals transmitted by two presently existing websites, poesia do google and MixLit - O DJ da Literatura, are addressed. In those proposals, above, exercising the uncreative writing can be read as an affirmative reaction of the XXI literature to its cultural and esthetical transformations experienced in times of digital media.

KEYWORDS: Uncreative Writing. Textual Appropriation. Authorship. Digital Media.

\section{Referências}


AUGUSTO, Danilo. Escamandro: poesia, tradução, crítica, 09 out. 2014. Poesia Flarf, por Danilo Augusto. Disponível em:

<https://escamandro.wordpress.com/2014/10/09/poesia-flarf-por-danilo-augusto/>. Acesso em: 10 mai. 2016.

AZEVEDO, Luciene. Pirataria literária tem valor? Abehache - Revista da Associação Brasileira de Hispanistas, São Paulo, n. 1, p. 43-58, 2011. Disponível em: <http://hispanismo.cervantes.es/documentos/pdf_revistaabache.pdf>. Acesso em: 13 mai. 2016.

BAKHTIN, Mikhail. Estética da criação verbal. Tradução de Paulo Bezerra. 4. ed. São Paulo: Editora Martins Fontes, 2003.

BARTHES, Roland. A morte do autor. O rumor da língua. Tradução de Mário Laranjeira. São Paulo: Brasiliense, 1988.

BORGES, Jorge Luis. Ficções. Tradução de Carlos Nejar. 3. ed. São Paulo: Globo, 1999.

CARNEIRO, Davi. poesiadogoogle.com. Disponível em <http://poesiadogoogle.com/comoparticipar>. Acesso em: 16 mai. 2016.

COMPAGNON, Antoine. O trabalho da citação. Tradução de Cleonice P.B. Mourão. Belo Horizonte: Ed. da UFMG, 2007.

DIÓGENES, Paulo César Rodrigues. Sobre máquinas de escrita e remistura: o método cut-up de William Burroughs. Línguas e Letras, Cascavel-PRM, n 25, p. 343-370, 2012.

FOUCAULT, Michel. O que é um autor? Tradução de António Fernando Cascais. Lisboa: Vega, 2002.

FOUCAULT, Michel. Arqueologia do saber. Tradução de Luiz Felipe Baeta Neves. Rio de Janeiro: Forense Universitária, 2005.

GOLDSMITH, Kenneth. Uncreative writing: managing language in the digital age. New York: Columbia University Press, 2011a.

GOLDSMITH, Kenneth. Valor econômico, São Paulo, 22 mar. 2013. Abaixo a criatividade! Entrevista concedida a Bruno Yutaka Saito. Disponível em: <http://www.valor.com.br/cultura/3056952/abaixo-criatividade>. Acesso em: 05 mai. 2016.

GOLDSMITH, Kenneth. Select, São Paulo, Editora Três, Out 2011b. Copiar é preciso, inventar não é preciso - entrevista concedida a Giselle BeiGuelman. Tradução de Luiz Roberto Mendes Gonçalves. Disponível em: <http://www.select.art.br/article/reportagens_e_artigos/copiar-e-preciso-inventarnao-e-preciso?page=unic>. Acesso em: 04 mai. 2016. 
KANT, Immanuel. Crítica da faculdade do juízo. Tradução de Valério Rohden e António Marques. 2. ed. Rio de Janeiro: Forense Universitária, 2005.

MARTINS, Beatriz Cintra. Autoria em rede: os novos processos autorais através das redes eletrônicas. Rio de Janeiro: Ed. Mauad, 2014.

MICHAELIS; Dicionário de Português Online. Disponível em: $<$ http://michaelis.uol.com.br/moderno/portugues/index.php?lingua=portuguesportugues\&palavra=autor>. Acesso em: 20 mai. 2016.

OLINTO, Heidrun Krieger. Processos midiáticos e comunicação literária. In: OLINTO, Heidrun Krieger; SCHOLLHAMMER, Karl Erik (Orgs.) Literatura e mídia. São Paulo: Loyola, 2002. p.54-75.

PERLOFF, Marjorie. O gênio não original; poesia por outros meios no novo século. Tradução de Adriano Scandolara. Belo Horizonte: UFMG, 2013.

CASSEL, Pedro. poesiadogoogle.com. Não é porque. Disponível em <http://poesiadogoogle.com/post/98091910280/n\%C3\%A3o-\%C3\%A9-porquesugest\%C3\%A3o-de-poesiadogoogle-enviada>. Acesso em: 15 mai. 2016.

RÓNAI, Cora (Org.). Caiu na Rede. Os textos falsos da internet que se tornaram clássicos. Rio de Janeiro: Agir, 2006.

SANTAELLA, Lúcia. Linguagens líquidas na era da mobilidade. São Paulo: Paulus, 2007.

SANTIAGO, Silviano. Uma literatura nos trópicos. 2. ed. Rio de Janeiro: Rocco, 2000.

SARLO, Beatriz. Jorge Luis Borges, um escritor na periferia. Tradução de Samuel Titan Jr. São Paulo: Iluminuras, 2008.

SCHNEIDER, Michel. Ladrões de palavras: ensaio sobre o plágio, a psicanálise e o pensamento. Tradução de Luiz Fernando P. N. Franco. Campinas: Editora da UNICAMP, 1990.

VILLA-FORTE, Leonardo. MixLit: O DJ da Literatura. Disponível em: <https://mixlit.wordpress.com/ >. Acesso em: 25 mai. 2016.

VILLA-FORTE, Leonardo. MixLit: O DJ da Literatura. MixLit 55: Uma visita à sra. Mercado. Disponível em: <https://mixlit.wordpress.com/category/atiq-rahimi/>. Acesso em: 25 mai. 2016.

VILLA-FORTE, Leonardo. baixacultura.org. A literatura sampleada do mixlit entrevista concedida ao site baixacultura.org. Disponível em: 
$<$ http://baixacultura.org/a-literatura-sampleada-do-mixlit/>. Acesso em: 12 mai. 2016.

Recebido em: 30/08/2016.

Aceito em: 07/12/2016. 